\title{
ANALISIS STUDI KELAYAKAN USAHA PENDIRIAN RICEBOWL IKAN TUNA SUWIR MANGATHAT DI MALANG
}

\author{
Purnomo*, Yurida Ekawati, Sunday Noya, Yuswono Hadi, Teguh Oktiarso, Novenda Kartika
}

Program Studi Teknik Industri, Universitas Ma Chung, Jl. Villa Puncak Tidar N-01, Malang, Indonesia, 65151

Correspondence: Purnomo (pur.nomo@machung.ac.id)

Received: 30 Juni 2021 - Revised: 01 Agustus 2021 - Accepted: 16 Agustus 2021

\begin{abstract}
Abstrak. Penelitian ini bertujuan untuk mengetahui tingkat kelayakan investasi dalam pendirian IKM ricebowl ikan tuna yang beralamat di Kelurahan Tegalgondo Kecamatan Karangploso Kabupaten Malang. Penelitian ini dilakukan di industri rumahan bernama IKM Ricebowl Ikan Tuna Suwir, yang merupakan Industri Kecil dan Menengah pengolah makanan. Terjadinya wabah Covid-19 di tahun 2020 ini mengakibatkan permintaan akan produk IKM menurun karena tempat kuliner yang menjalin kerjasama masih menutup usahanya. Penelitian dilaksanakan pada Bulan Juni - Juli 2020 dengan teknik pengumpulan data berupa observasi, wawancara, dan dokumentasi. Metode yang digunakan yaitu aspek pasar dan pemasaran, aspek teknis dan produksi, aspek organisasi dan manajemen, serta aspek finansial dengan perhitungan kelayakan investasi berupa Payback Period (PP) (Present Value) usaha makanan ricebowl akan menghasilkan manfaat bersih sebesar Rp. 276.258.850. dengan umur usaha 4 tahun. Nilai IRR (Internal Rate of Return) yang diperoleh sebesar 36\%>15, 20\% (IRR >DR). Nilai ini menunjukan bahwa tingkat pengembalian usaha IKM ricebowl dalam kondisi optimal. Analisis pasar dan pemasaran menunjukkan bahwa prospek IKM ricebowl ikan tuna cukup baik, dilihat dari peningkatan jumlah permintaan setiap tahun.
\end{abstract}

Kata kunci: IKM, studi kelayakan, ricebowl, studi kelayakan bisnis

Citation Format: Purnomo, Ekawati, Y., Noya, S., Hadi, Y., Oktiarso, T. \& Kartika, N. (2021). Analisis Studi Kelayakan Usaha Pendirian Ricebowl Ikan Tuna Suwir Mangathat di Malang. Prosiding Seminar Nasional Abdimas Ma Chung (SENAM), 143-153. 


\section{PENDAHULUAN}

Secara alamiah, proses pembangunan ekonomi di suatu negara menimbulkan kesempatan yang besar bagi seluruh kegiatan ekonomi, termasuk industri dari berbagai skala usaha, mulai dari usaha kecil, menengah, maupun usaha besar. Industri Kecil Menengah (IKM) mempunyai peranan penting dalam memberikan kontribusi bagi perekonomian suatu negara. IKM juga berperan penting di negara-negara yang sedang berkembang terutama terhadap penanggulangan tingkat kemiskinan, jumlah pengangguran, distribusi pendapatan, dan penyerapan tenaga kerja.

Salah satu aktivitas yang paling diminati terutama bagi kaum perempuan yang memiliki banyak waktu luang karena tidak terlibat aktif dalam pekerjaan publik adalah usaha makanan. (Rini, 2018) Dalam kegiatan ekonomi, maka didirikan Usaha dibidang usaha kuliner yang telah terwujud adalah IKM usaha ricebowl ikan tuna mangathat dan pengelolaan ikan suwir. IKM usaha ricebowl ikan tuna ini berada di perumahan IKIP yang terletak di Desa Tegalgondo Kecamatan Karangploso Kabupaten Malang. (IKM) usaha ricebowl ikan tuna Mangathat di Malang yang proses pengolahan masih tradisional atau manual. Kebutuhan dasar bagi manusia yang terus meningkat seiring dengan peningkatan jumlah penduduk. Salah satu upaya untuk memenuhi kebutuhan pangan dapat dilakukan dengan cara meningkatkan budidaya dan pemanfaatan hasil perikanan seperti komoditas ikan merupakan salah satu komoditi unggulan bagi Indonesia. Keberadaan usaha ricebowl ikan di berbagai wilayah menciptakan persaingan yang cukup tinggi mengingat pasar yang dituju relatif sama. Pesaing yang dihadapi oleh IKM Mangathat ternyata bukan hanya pengusaha ricebowl ikan dari daerah lain tetapi juga pengusaha ricebowl ikan dari daerah Kabupaten Malang sendiri. Seiring dengan berjalannya waktu, ternyata usaha abon ikan Mangathat belum mengalami perkembangan yang signifikan. IKM olahan ikan Mangathat ternyata masih dikelola secara sederhana baik dari segi manajemen, produksi,pemasaran dan keuangan. Dengan teknologi yang baik diharapkan dapat menghasilakn profit yang baik bagi IKM tersebut. Di tahun 2020 ini, dunia sedang dilanda wabah penyakit yang disebabkan oleh Covid-19. Penyakit ini bersifat menular melalui droplet atau percikan pernapasan yang terdiri dari air dan jatuh ke tanah dengan cepat setelah diproduksi. 
Covid-19 sangat berdampak pada masyarakat dunia baik dalam bidang kesehatan, perekonomian maupun pendidikan. Sebesar 70\% UMKM di Indonesia menghentikan kegiatan produksinya karena permintaan menurun selama wabah Covid-19. Selain itu masalah yang dialami oleh IKM adalah terputusnya kerjasama dengan mitra bisnis. Menurut Muhyiddin (2020), Indonesia tengah berjuang melawan Covid-19 dengan memodifikasi kebijakan karantina wilayah (lockdown) menjadi Pembatasan Sosial Berskala Besar (PSBB). Pada bulan Juli, pemerintah Indonesia mengeluarkan strategi untuk menghadapi wabah dengan penerapan new normal.

Menurut Ketua Tim Pakar Gugus Tugas Percepatan Penangan Covid-19 RI, menyebutkan bahwa new normal adalah perubahan perilaku untuk menjalankan kehidupan normal dengan penerapan protokol kesehatan guna mencegah penyebaran Covid-19. Protokol new normal adalah menggunakan masker, menjaga jarak aman yaitu 1 meter, mencuci tangan dan isolasi mandiri. Harapan dari strategi new normal ini adalah banyak sektor dapat kembali beroperasioanal dengan mengikuti anjuran protokol kesehatan.

Pengembangan usaha makanan ricebolw ikan tuna di tengah masa new normal ini membutuhkan analisis kelayakan usaha. Aspek yang akan dikaji dalam analisis kelayakan adalah aspek pasar, aspek legalitas, aspek teknis, serta aspek finansial. Aspek pasar akan mengkaji perihal target pasar dari IKM ricebowl serta strategi pemasaran apa yang digunakan agar usaha dapat berkembang dan bertahan dari kompetitornya. Aspek teknis akan mengkaji perihal mesin dan peralatan produksi, kapasitas produksi, tata letak produksi serta lokasi usaha saat ini.

\section{TINJAUAN PUSTAKA}

\section{Studi Kelayakan Bisnis}

Studi Kelayakan Bisnis Studi Kelayakan bisnis adalah suatu kegiatan yang mempelajari secara mendalam tentang kegiatan atau usaha atau bisnis yang akan dijalankan, dalam rangka menentukan layak atau tidak usaha tersebut dijalankan, (Kasmir dan Jakfar,2003:10), objek yang diteliti tidak hanya pada bisnis atau usaha yang besar saja, tapi pada bisnis atau usaha yang sederhana bisa juga diterapkan. 
Tujuan dilakukan studi kelayakan: paling tidak ada lima tujuan mengapa sebelum suatu usaha atau bisnis dijalankan perlu dilakukan studi kelayakan (Kasmir Jakfar,2003:20), yaitu :

Menghindari resiko kerugian untuk mengatasi resiko kerugian di masa yang akan datang ada semacam kondisi kepastian. Kondisi ini ada yang dapat diramalkan akan terjadi atau memang dengan sendirinya terjadi tanpa dapat diramalkan. Dalam hal ini fungsi studi kelayakan adalah untuk meminimalkan resiko yang tidak kita inginkan, baik resiko yang dapat kita kendalikan maupun yang tidak dapat dikendalikan.

Memudahkan perencanaan jika kita sudah dapat meramalkan apa yang akan terjadi di masa yang akan datang, maka akan mempermudah kita dalam melakukan perencanaan dan hal - hal apa saja yang perlu direncanakan. Memudahkan pelaksanaan pekerjaan dengan adanya berbagai rencana yang sudah disusun akan sangat memudahkan pelaksanaan usaha. Para pelaksana yang mengerjakan bisnis tersebut telah memiliki pedoman yang harus diikuti. Pedoman tersebut telah tersusun secara sistematis, sehingga usaha yang dilaksanakan dapat tepat sasaran dan sesuai dengan rencana yang sudah disusun.

Memudahkan pengawasan dengan telah dilaksanakannya suatu usaha sesuai dengan rencana yang sudah disusun, maka akan memudahkan kita untuk melakukan pengawasan terhadap jalannya usaha. Pengawasan ini perlu dilakukan agar tidak melenceng dari rencana yang telah disusun. Memudahkan pengendalian apabila dalam pelaksanaan pekerjaan telah dilakukan pengawasan, maka jika terjadi penyimpangan akan mudah terdeteksi, sehingga dapat dilakukan pengendalian atas penyimpangan tersebut. Tujuan pengendalian adalah untuk mengendalikan pelaksanaan agar tidak melenceng dari rel yang sesungguhnya, sehingga pada akhirnya tujuan perusahaan akan tercapai.

\section{Aspek-aspek Studi Kelayakan Bisnis}

Menurut Husein Umar dalam bukunya Studi Kelayakan Bisnis, Manajemen, Metode dan Kasus, 1997:10, aspek-aspek dalam studi kelayakan meliputi:

\section{a. Aspek Teknis Evaluasi}

Aspek teknis ini mempelajari kebutuhan-kebutuhan teknis proyek, seperti penentuan kapasitas produksi, jenis teknologi yang digunakan, pemakaian peralatan dan mesin, serta lokasi usaha yang paling menguntungkan. 


\section{b. Aspek Pasar dan Pemasaran}

Evaluasi aspek pasar dan pemasaran sangat penting dilakukan karena tidak ada usaha yang berhasil tanpa adanya permintaan atas barang atau jasa yang dihasilkan oleh usaha tersebut. Pada dasarnya, aspek pasar dan pemasaran bertujuan untuk mengetahui berapa besar luas pasar, pertumbuhan permintaan dan pangsa pasar produk atau jasa yang bersangkutan.

\section{c. Aspek Yuridis}

Evaluasi terhadap aspek yuridis perlu dilakukan. Bagi pemilik usaha, evaluasi ini berguna antara lain untuk kelangsungan usaha serta dalam rangka meyakinkan para kreditur dan investor bahwa usaha yang akan dilakukan tidak menyimpang dari aturan yang berlaku.

\section{d. Aspek Manajemen}

Dalam aspek manajemen yang dievaluasi ada dua macam, yang pertama manajemen saat pembangunan usaha dan yang kedua manajemen saat usaha dioperasionalkan. Banyak terjadi usaha-usaha yang gagal dibangun maupun dioperasionalkan bukan disebabkan karena aspek lain, tetapi karena lemahnya manajemen.

\section{e. Aspek Lingkungan}

Pertumbuhan dan perkembangan perusahaan tidak dapat dilepaskan dari lingkungan sekitarnya. Lingkungan ini dapat berpengaruh positif maupun negatif perusahaan, sehingga studi kelayakan aspek ini perlu dianalisis pula.

\section{f. Aspek Finansial}

Dari sisi keuangan, usaha sehat dikatakan apabila dapat memberikan keuntungan yang layak dan mampu memenuhi kewajiban finansialnya. Kegiatan ini dilakukan setelah aspek lain selesai dilaksanakan. Kegiatan pada aspek finansial ini antara lain menghitung perkiraan jumlah dana yang diperlukan untuk keperluan modal awal dan untuk pengadaan harta tetap usaha. 


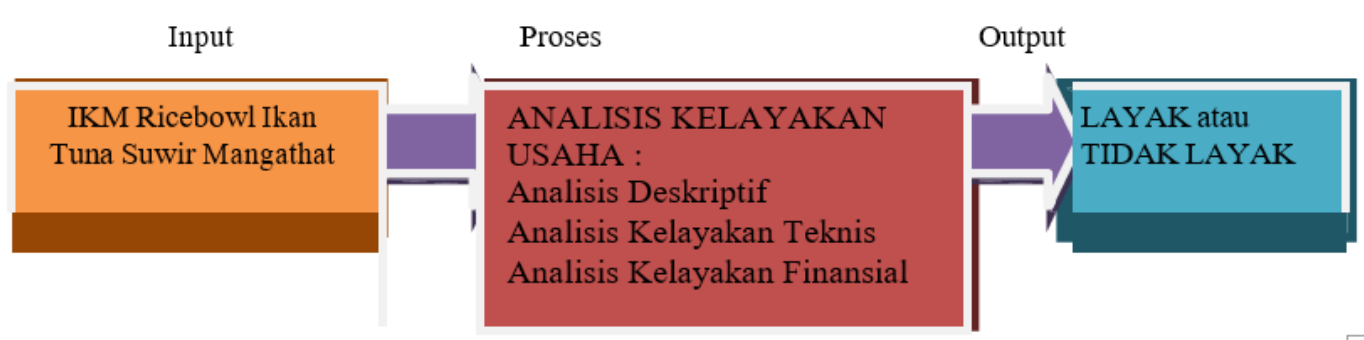

Gambar 1. Kerangka Pemikiran (Sumber: data yang diolah)

\section{Aspek Non Finansial}

Peranan aspek pasar dalam pendirian maupun perluasan usaha pada studi kelayakan proyek maupun studi kelayakan bisnis merupakan variabel pertama atau yang utama untuk mendapatkan perhatian. Pengembangan usaha IKM ricebowl ikan tuna dikatakan layak apabila tidak terdapat masalah dalam pemasarannya yang dapat menghambat proses pengembangan usaha IKM ricebowl ikan tuna mangathat. Aspek teknis merupakan suatu aspek yang berkenaan dengan proses pembangunan proyek secara teknis dan pengoperasiannya, pelaksanaan aspek teknis dilakukan setelah evaluasi aspek pasar yang menunjukan adanya kesempatan pemasaran yang memadai untuk jangka waktu yang relatif panjang. IKM ricebowl ikan tuna dapat dikatakan layak apabila sarana berupa bangunan, luas produksi, tata letak perusahaan sesuai sehingga mampu melancarkan proses produksi, pemilihan teknologi yang tepat sehingga tidak menghambat usaha.

\section{Aspek Finansial}

Evaluasi aspek finansial biasanya dilakukan setelah evaluasi aspek-aspek lain selesai dilakukan, Selama evaluasi aspek ini dihitung perkiraan jumlah dana yang diperlukan, baik untuk pengadaan investasi proyek maupun kebutuhan dana modal kerja awal. Disamping jumlah kebutuhan dana pembiayaan dan sumber dana, juga akan dipelajari struktur pembiayaan bagaimana yang paling menguntungkan dan berapa bagian dari jumlah kebutuhan dana tersebut dapat atau wajar untuk dibiayai dengan pinjaman dari pihak ketiga, dari mana sumbernya dan berapa biayanya. Dari segi keuangan atau finansial, proyek dikatakan layak apabila dapat memberikan keuntungan dan mampu memenuhi kewajiban finansialnya. Net Present Value (NPV) atau nilai bersih sekarang yaitu selisih antara present Value dari investasi dengan nilai sekarang dan penerimaanpenerimaan bersih dimasa yang akan datang (Umar,2003: 200). Rumus NPV adalah 


$$
N P V=\sum_{i=1}^{n} \overline{B_{i}}-\overline{C_{i}}=\sum_{i=1}^{n} N \bar{B}_{i}
$$

Keterangan:

$\mathrm{B}_{\mathrm{t}}=$ Penerimaan pada tahun $\mathrm{t}$

$\mathrm{C}_{\mathrm{t}}=$ Biaya-biaya pada tahun $\mathrm{t}$

$\mathrm{T}=$ Tahun kegiatan bisnis

$\mathrm{I}=$ Tingkat discount rate (DR)

Internal Rate of Return (IRR) merupakan metode yang digunakan untuk mencari tingkat bunga yang menyamakan nilai sekarang dari arus kas yang diharapkan dimasa datang atau penerimaan kas, dengan mengeluarkan investasi awal (Umar, 2003:198). Sebelum menghitung IRR harus ditentukan terlebih dahulu nilai PV (Present Value), dengan menggunakan rumus :

\section{$\mathrm{PV}=$ Net CashFlow $\mathrm{x}$ Discount Factor}

\section{Keterangan :}

Net CashFlow $=$ Laba bersih setelah pajak

Discount Factor $=$ Persen di dapat dari tabel bunga

Setelah itu menghitung IRR dengan menggunakan rumus:

$$
I R R=P 1-C 1 x \frac{P 2-P 1}{C 2-C 1}
$$

Keterangan :

P1 = tingkat bunga ke-1

P2 = tingkat bunga ke-2

$\mathrm{Cl}=$ NPV ke-1

$\mathrm{C} 2=\mathrm{NPV}$ ke-2

Payback Period (PP) adalah suatu periode yang menunjukkan berapa lama modal yang ditanamkan dalam proyek tersebut dapat kembah (Rangkuti, 2004: 214). Rumus PP adalah 


$$
P P=\frac{\text { Nilai Investasi }}{\text { Kas Masuk Bersih }} x 1 \text { tahun }
$$

Keterangan :

Jika Payback Period menghasilkan waktu yang pendek dari maksimum Payback periode-nya, maka usulan investasi dinyatakan layak/ diterima.

\section{METODE PELAKSANAAN}

Tujuan penelitian ini adalah untuk menganalisis kelayakan usaha pada IKM ricebowl ikan tuna mangathat, penelitian dianalisis secara kualitatif dan kuantitatif. Analisis kualitatif meliputi aspek-aspek non finansial seperti aspek pasar, aspek teknis, aspek manajemen dan SDM, aspek hukum, aspek sosial ekonomi dan budaya, dan aspek lingkungan. Sedangkan untuk analisis kuantitatif meliputi aspek-aspek finansial seperti data penjualan, biaya-biaya opersional, dan investasi pada pengembangan usaha IKM ricebowl ikan tuna.

\section{Lokasi Penelitian}

Penelitian Studi Kelayakan Usaha Pendirian ricebowl Ikan Tuna Suwir Mangathat ini dilakukan pada Industri Kecil Menengah Ricebowl Ikan tuna suwir mangathat yang beralamat di Perumahan Guru Blok B No 3 Kelurahan Tegalgondo, Kecamatan Karangploso, Kabupaten Malang.

\section{Pengumpulan Data}

Tahapan pertama yang peneliti lakukan adalah mengidentifikasi masalah, dengan datang langsung ke IKM ricebowl ikan tuna. Hal ini dilakukan untuk mengetahui informasi tentang masalah yang akan diteliti serta melihat kelayakan usaha di IKM tersebut sehingga dalam penyelesaian masalah peneliti tidak mengalami kendala yang berarti. Permasalahan yang akan dibahas dilihat dari aspek finansial dan non finansial.

Setelah permasalahan ditentukan langkah selanjutnya adalah mengumpulkan data-data dari IKM ricebowl ikan tuna yaitu: melakukan wawancara langsung dengan pemilik, observasi langsung di IKM, dan searching internet. Jika ada data yang tidak bisa didapatkan dari Industri kecil dan menengah maka peneliti melakukan asumsi terhadap data tersebut. Setelah data-data yang diperlukan didapat dilakukan pengolahan data. Pengolahan data 
tidak hanya berisi data angka saja tetapi juga solusi perbaikan kelayakan IKM ricebowl ikan tuna mangathat.

\section{HASIL DAN PEMBAHASAN}

\section{Analisis Aspek Non Finansial}

Berdasarkan hasil analisis aspek non finansial, pada tahun 2016 pengembangan usaha Ricebowl Ikan Tuna suwir mangthat dinilai dari aspek pasar sudah mengkondisikan pemasaran dengan baik dan lancar, namun masih terdapat 57,20\% peluang pasar yang masih terbuka, aspek pasar masih terus dapat berkembang pesat mengingat pengguna kuliner juga semakin meningkat, pemasaran yang terus meningkat dijadikan peluang oleh IKM ricebowl ikan tuna untuk terus mengembangkan usahanya dan diharapkan dapat meningkatkan pesanan dan keuntungan untuk IKM ricebowl ikan tuna mangathat.

\section{Perhitungan NPV, IRR, Payback Period,}

Perhitungan NPV (Net Present Value) dilakukan untuk mengetahui nilai sekarang (Present Value) manfaat bersih yang diperoleh selama periode usaha. Pada perhitungan analisis kelayakan usaha diperoleh nilai NPV (Net Present Value ) sebagai berikut:

Tabel 3.1 Perhitungan Kriteria Investasi NPV (Net Present Value)

\begin{tabular}{lccccccc}
\hline \multicolumn{2}{l}{$\begin{array}{l}\text { No. Investasi. } \\
\text { Value }\end{array}$} & Biaya Operasi & Total Cost. & Benefit. & Net Benefit. & D.F 15,20 \%. Present \\
& $\mathrm{Rp}$. & $\mathrm{Rp}$. & $\mathrm{Rp}$. & $\mathrm{Rp}$ & $\mathrm{Rp}$ & $\mathrm{Rp}$ \\
\hline 0 & 36.750 .000 & - & - & - & 36.750 .000 & 1 & 36.750 .000 \\
1 & & 74.500 .000 & 74.500 .000 & 89.200 .000 & 17.750 .000 & 0,24 & 42.600 .000 \\
2 & 85.680 .000 & 85.680 .000 & 97.500 .000 & 19.930 .000 & 0,22 & 43.846 .000 \\
3 & 167.760 .500 & 167.760 .500 & 115.000 .000 & 56.760 .500 & 0,12 & 67.212 .600 \\
4 & 245.790 .000 & 245.760 .000 & 125.250 .000 & 78.210 .000 & 0,11 & 85.850 .250 \\
\hline \multicolumn{5}{c}{ NPV $=$} \\
\hline
\end{tabular}

Untuk mengetahui kelayakan suatu pendirian usaha melalui IRR (Internal Rate of Return), maka harus dibandingkan dengan cost of capital. Nilai cost of capital yang digunakan sebesar 15,20\%. Pada perhitungan analisis kelayakan usaha diperoleh nilai IRR (Internal Rate of Return ) sebagai berikut: 
Tabel 3.2 Tabel Kriteria Investasi IRR (Internal Rate of Return)

\begin{tabular}{|c|c|c|c|c|c|c|}
\hline No. & $\begin{array}{c}\text { Investasi. } \\
\text { Rp. }\end{array}$ & $\begin{array}{c}\text { Net Benefit } \\
\text { Rp. }\end{array}$ & D.F $15,20 \%$. & $\begin{array}{c}\text { Present Value. } \\
\mathrm{Rp} \\
\end{array}$ & D.F $20,15 \%$ & $\begin{array}{c}\text { Present Value } \\
\mathrm{Rp} \\
\end{array}$ \\
\hline $\begin{array}{l}0 \\
1 \\
2 \\
3 \\
4\end{array}$ & 36.750 .000 & $\begin{array}{r}36.750 .000 \\
17.750 .000 \\
85.680 .000 \\
167.760 .500 \\
245.790 .000\end{array}$ & $\begin{array}{c}1 \\
0,24 \\
0,22 \\
0,12 \\
0,11\end{array}$ & $\begin{array}{l}36.750 .000 \\
42.600 .000 \\
43.846 .000 \\
67.212 .600 \\
85.850 .250\end{array}$ & $\begin{array}{c}1 \\
0,23 \\
0,21 \\
0,11 \\
0,10\end{array}$ & $\begin{array}{l}36.750 .000 \\
35.850 .000 \\
31,650.000 \\
65.850 .150 \\
79.930 .250\end{array}$ \\
\hline 4 & & & $\mathrm{NPV}=$ & 276.258 .850 & & 250.030 .400 \\
\hline
\end{tabular}

$$
I R R=0,1520+\frac{276.258 .850}{276.258 .850+250.030 .400}(0,20-0,1520)=0,36=36 \%
$$

\section{Analisis Aspek Finansial}

Hasil perhitungan yang dilakukan untuk mengetahui nilai sekarang (Present Value) selama periode usaha, diperoleh nilain NPV (Net Present Value) sebesar Rp. 276.258.850 yang berarti bahwa usaha ricebowl ikan tuna akan menghasilkan manfaat bersih sebesar Rp.276.258.850 yang diperoleh selama umur usaha 4 tahun. Karena dari hasil analisis di atas di dapat nilai NPV > 0 maka pengembangan usaha ini layak untuk dijalankan. Hasil perhitungan menunjukan bahwa nilai IRR (Internal Rate of Return) yang diperoleh sebesar 36\%, nilai ini menunjukan bahwa tingkat pengembalian usaha ricebowl ikan tuna dalam kondisi optimal. Kriteria investasi ini memiliki nilai yang lebih besar dari cost of capital yang telah ditentukan sebesar 15,20\% (IRR $>$ DR), sehingga pengembangan usaha IKM ricebowl layak untuk dijalakan.

\section{KESIMPULAN}

Setelah dilakukan analisis perhitungan dengan menggunakan pemrogaman dinamis (penggatian alat) didapatkan hasil sebagai berikut:

1. Berdasarkan hasil analisis aspek non finansial, pada tahun 2016 pengembangan usaha Indutri Kecil Menengah ricebowl ikan tuna mangathat dinilai dari aspek pasar sudah melaksanakan pemasaran dengan baik dan lancar, namun masih terdapat 57,20\% peluang pasar yang masih terbuka, aspek pasar masih terus dapat berkembang pesat mengingat kuliner juga semakin meningkat seiring dengan meningkatnya jumlah Mahasiswa. 
2. Berdasarkan hasil perhitungan yang dilakukan untuk mengetahui nilai sekarang (Present Value) selama periode usaha, usaha makanan ricebowl akan menghasilkan manfaat bersih sebesar Rp. 276.258.850. dengan umur usaha 4 tahun. Nilai IRR (Internal Rate of Return) yang diperoleh sebesar 36\%>15, 20\% (IRR>DR). Nilai ini menunjukan bahwa tingkat pengembalian usaha IKM ricebowl ikan tuna mangathat dalam kondisi optimal dan layak untuk dijalakan.

\section{UCAPAN TERIMA KASIH}

Ucapan terima kasih ditujukan kepada semua pihak yang terlibat dalam pembuatan naskah ini dan pihak masyarakat. Ucapan terima kasih dapat pula ditujukan kepada penyedia dana atau sponsor.

\section{DAFTAR PUSTAKA}

Rini, A. (2018) Strategi Pengembangan Usaha Abon Ikan Di Kub Hurip Mandiri Kecamatan Cisolok Kabupaten Sukabumi.

Umar, H., (1997). Metode Penelitian, Aplikasi dalam Pemasaran, Jakarta.

Kasmir. (2008). Analisis Laporan Keuangan. Edisi Revisi. Jakarta: PT. Raja Grafindo. Kasmir and Jakfar, (2003). Studi Kelayakan Bisnis, Kencana Prenada Media, Jakarta.

Kasmir dan Jakfar. (2004). Studi Kelayakan Bisnis. Jakarta: Kencana.

Muhyiddin. (2020). Covid-19, New Normal dan Perencanaan Pembangunan di Indonesia. The Indonesian Journal of Development Planning, 240- 252.

Umar. (2003). Metode Riset Perilaku Konsumen Jasa. Jakarta: Ghalia Indonesia

Rangkuti, Freddy. 2004. Manajemen Persediaan Aplikasi di Bidang Bisnis. Jakarta : PT. Raja Grafindo Persada.

\section{(c) (i)}

(C) 2021 by authors. Content on this article is licensed under a Creative Commons Attribution 4.0 International license. (http://creativecommons.org/licenses/by/4.0/). 